\title{
Improvement of the lactic acid fermentation of capers (Capparis spinosa L) through an experimental factorial design
}

\author{
By H. Douieb, ${ }^{1 *}$ M. Benlemlih, ${ }^{2}$ and F. Errachidi ${ }^{3}$ \\ ${ }^{1}$ University Sidi Mohamed Ben Abdelah. Faculty of Sciences Dhar El Mehraz \\ Department of Biology, Fez, Morocco \\ ${ }^{2}$ University Sidi Mohamed Ben Abdelah. Faculty of Sciences Dhar El Mehraz \\ Department of Biology, Fez, Morocco \\ ${ }^{3}$ University Sidi Mohamed Ben Abdelah. Faculty of Sciences Dhar El Mehraz \\ Department of Biology, Fez, Morocco \\ ( ${ }^{*}$ Corresponding author: hicham.douieb @ yahoo.fr)
}

\section{RESUMEN}

\begin{abstract}
Mejora de la fermentación ácido láctica de alcaparras (Capparis spinosa $\mathrm{L}$ ) mediante un diseño factorial.
\end{abstract}

El estudio del proceso de fermentación mediante un diseño factorial nos permitió determinar una función $f(Y=$ $\left.f\left(X_{1}, X_{2}, \ldots, X_{n}\right)\right)$ que existe entre la magnitud $Y$ que es la disminución del pH (llamada respuesta), y las variables $X$, que son la salmuera, ácido láctico, ácido cítrico y los fermentos lácticos (llamados factores). Un completo plan factorial $2^{4}$ fue hecho con objeto de determinar los factores y las interacciones entre los factores que tienen una influencia estadísticamente significativa en la respuesta estudiada. La salmuera, ácido láctico y ácido cítrico tienen un efecto significativo en la caída del pH; por el contrario, los fermentos lácticos no tienen efecto significativo. Por otra parte, las interacciones entre salmuera y ácido láctico, salmuera y fermentos lácticos, ácido láctico y ácido cítrico, y ácido láctico y fermentos lácticos tuvieron un efecto significativo en la caída del $\mathrm{pH}(\mathrm{p}$ $<0.0001$ ). La fermentación fue hecha en el laboratorio de investigación de la Sociedad Marocapres-Fez líder Internacional en la transformación de alcaparras, a una temperatura de aproximadamente $30^{\circ} \mathrm{C}$ entre los meses de junio y julio.

PALABRAS CLAVE: Ácido cítrico - Ácido láctico - Alcaparras - Capparis spinosa - Fermentos lácticos - Salmuera.

\section{SUMMARY}

Improvement of the lactic acid fermentation of capers through an experimental factorial design (Capparis spinosa L).

The study of the caper fermentation process through an experiment factorial plan allows us to determine a function $f$ such that $\left(Y=f\left(X_{1}, X_{2}, \ldots, X_{n}\right)\right)$ existing between magnitude $Y$ which is the decrease of $\mathrm{pH}$ (called response), and variables $\mathrm{X}_{\mathrm{i}}$, which are brine, lactic acid, citric acid and lactic ferment (called factors). A complete factorial plan $2^{4}$ was made in order to determine the factors and the interactions among the factors which have a statistically significant influence on the studied response. Brine, lactic acid and citric acid have a significant effect on the fall of $\mathrm{pH}$; by contrast, lactic ferment does not have a significant effect. On the other hand, the interactions between brine and lactic acid, between brine and lactic ferment, between lactic acid with citric acid and between lactic acid with lactic ferment have significant effects on the fall of $\mathrm{pH}(\mathrm{p}<0.0001)$. The fermentation was done in the research laboratory of the society Marocapres$\mathrm{Fez}$, international leader in the processing of capers, at a temperature of about $30^{\circ} \mathrm{C}$, between June and July.

KEY-WORDS: Brine - Capers - Capparis spinosa Citric acid - Lactic acid - Lactic ferment

\section{INTRODUCTION}

The caper is a shrub which is well known in the countries of the Mediterranean Basin. It belongs to the family of Capparidaces and the genus Capparis which contains more than 350 species used for different purposes (food, traditional medicine, ornamentation, cosmetics ...). The flower bud is called "capers" while the fruit of this shrub is called "Caperberries". The picking of capers and caperberries is manual and done between May and August. Morocco, Spain, Italy and Turkey are the main worldwide producers (Giuffrid et al., 2002).

Concerning their use in the kitchen, the caper and caperberries are mainly used (Akgül, 1996).

The habitual treatment of capers consists of submerging the capers freshly harvested in a solution of salt ( $24 \%$ by weight) for about 40 days (Giuffrid et al., 2002) until fermentation takes place and the bitter taste resulting from glycoside, called glucocapparin, disappears (Arslan et al., 2007).

The direct addition of selected starter cultures to raw materials has been a breakthrough in the processing of fermented foods, resulting in a high degree of control over the fermentation process and standardization of the end product (Oberman and Libudzisz, 1998; Leroy and De Vuyst, 2004). Lactobacillus plantarum has been successfully used as a starter culture in several food fermentations (McDonald et al., 1993; Aukrust et al., 1994; Giraud et al., 1994; Gardner et al., 2001; Leal-Sánchez et al., 2003; Mugula et al., 2003; Tolonen et al., 2004). L. plantarum has been noted for its acid production and tolerance to high salt concentrations (Fleming 
and Mc Feters, 1981) and for its superior ability to utilize the substrates (Oyewole and Odunfa, 1990), including dextrins after the depletion of fermentable sugars (Akinrele, 1970) and raw starch (Giraud et al., 1994; Mugula et al., 2003). Also, Lactobacillus acidophilus and L. plantarum have the ability to produce a greater amount of lactic acid than Lactobacillus casei and Lactobacillus delbrueckii (Yoon et al., 2005). For this reason, L. plantarum is used in this assay.

Recently, capers have started to gain increasing economic importance in the world market and demands are continuously increasing (Arslan et al., 2007). This pushed the caper processing industry to improve their fermentation conditions. Thus, this research has been designed to integrate this perspective of improvement and it aims at determining, for the first time, the best values of factors and the best combinations between the factors susceptible to reach a decrease in $\mathrm{pH}$ in order to inhibit the growth of undesirable microorganisms and consequently to obtain a good fermentation.

\section{MATERIALS AND METHODS}

\subsection{Materials}

The capers used in this study were collected in the early morning from wild growing plants in the fez region in June 2008 and transported in cool bags to the laboratory. The buds were separated from foreign materials such as stalk, leaves and dust before being processed. A commercial lyophilized starter culture (L. plantarum) was used in the assay,(Chr-Hansen Vege-Start 10, Horsholm, Denmark). Clear water and small-grain salt were used in the preparation of brine. Lactic and citric acids (S D Fine - Chem limited- Numbai-India) were commercial products.

\subsection{Experimental Design}

Many factors can significantly influence the fermentation of capers. The bibliographical data have urged us to study four factors: brine, lactic acid, citric acid and lactic ferment. This study was realized according to a plan of factorial experience wherein the calculation of the coefficients of the polynomial model has been accomplished through the method of "least squares" with the use of coded variables. In fact, the act of replacing the natural variables by coded variables allows for the same domain of variation for each factor (between -1 and +1 ) and hence being able to compare the effect of factors among themselves. The lowest level is coded -1 while the highest level is coded +1 (Table 1).

A complete factorial plan with 4 factors and $\mathrm{N}$ (number of tries) has been designed which will be equal to $16=(24)$, in this study we have conducted 3 replicates for each trial.

A summary of the the total tests can be seen in Table 2, which we have called "Table of Experiments".
Table 1

Levels of variables (factors)

\begin{tabular}{lcc}
\hline FACTORS & \multicolumn{2}{c}{ LEVELS } \\
& $\mathbf{- 1}$ & $\mathbf{+ 1}$ \\
\hline Brine & $10 \%$ & $20 \%$ \\
Lactic acid & $0.1 \%$ & $1 \%$ \\
Citric acid & $0.1 \%$ & $1 \%$ \\
Lactic ferment & $0.5 \%$ & $2,5 \%$ \\
\hline
\end{tabular}

\subsection{Brining procedure of capers}

Caper buds of medium size were put in 1-L sterilized glass jars and brined. Sixteen brine (called cover juice) types were used for the fermentation of caper buds (see table 2). After adding the cover juice (brine added to lactic acid, citric acid and lactic ferment), the jars were hermitically closed and left to ferment at the room temperature of the laboratory (about $30^{\circ} \mathrm{C}$ ) for 6 weeks. 3 repetitions were carried out for each trial.

A sample was taken every 2 weeks to measure the chemical and microbiological parameters of the samples.

\subsection{Chemical analysis of the cover juice}

A measurement of the $\mathrm{pH}$ of the juice was taken every 2 weeks of fermentation time (T0, T1, T2, and $\mathrm{T3}$ ), using a $\mathrm{pH}$ meter (Hanna $\mathrm{HI}$ 831) regularly calibrated with buffer solutions as $\mathrm{pH} 4.0$ and 7.0. The average $\mathrm{pH}$ values measured are represented in table 3 (column response $\mathrm{Y}$ ).

\subsection{Statistical Analysis}

The statistical calculations (calculation of coefficients, $t$ test, analysis of variance, curve ...) were done using the JMP software.

\section{RESULTS AND DISCUSSION}

On the basis of table 3 , the mathematical model is written as follows and has the form:

(1) $Y=a_{0}+a_{1} X_{1}+a_{2} X_{2}+a_{3} X_{3}+a_{4} X_{4}+a_{12} X_{1}$ $X_{2}+a_{13} X_{1} X_{3}+a_{14} X_{1} X_{4}+a_{23} X_{2} X_{3}+a_{24} X_{2} X_{4}+a_{34}$ $+\mathrm{X}_{3} \mathrm{X}_{4}$

To be able to conduct the statistical calculations and prevent that $n=p,(n=$ number of tests and $p$ the number of estimated parameters starting from the model, in other words, the number of the model's coefficients), it is necessary to neglect the high interactions of order (3 or more). This is the case in this study.

Or:

$Y:$ is the measured response during the experiment.

$a_{0}, a_{1} \ldots a_{4}, a_{12} \ldots \ldots \ldots a_{34}$ : are the mathematical coefficients of the model (the factors' average effects and the factors' interactions). 
Table 2

Table of experiments

\begin{tabular}{ccccc}
\hline $\mathbf{N}^{\circ}$ test & Brine & Lactic acid & Citric acid & Lactic ferment \\
\hline 1 & $10 \%$ & $0.1 \%$ & $0.1 \%$ & $0.5 \%$ \\
2 & $20 \%$ & $0.1 \%$ & $0.1 \%$ & $0.5 \%$ \\
3 & $10 \%$ & $1 \%$ & $0.1 \%$ & $0.5 \%$ \\
4 & $20 \%$ & $0.1 \%$ & $0.5 \%$ \\
5 & $10 \%$ & $1 \%$ & $1 \%$ & $0.5 \%$ \\
6 & $20 \%$ & $0.1 \%$ & $1 \%$ & $0.5 \%$ \\
7 & $10 \%$ & $0.1 \%$ & $1 \%$ & $0.5 \%$ \\
8 & $20 \%$ & $1 \%$ & $1 \%$ & $2.5 \%$ \\
9 & $10 \%$ & $1 \%$ & $0.1 \%$ & $2.5 \%$ \\
10 & $20 \%$ & $0.1 \%$ & $0.1 \%$ & $2.5 \%$ \\
11 & $10 \%$ & $0.1 \%$ & $0.1 \%$ & $2.5 \%$ \\
12 & $20 \%$ & $1 \%$ & $0.1 \%$ & $2.5 \%$ \\
14 & $10 \%$ & $1 \%$ & $1 \%$ & $2.5 \%$ \\
& $20 \%$ & $1 \%$ & $1 \%$ & $2.5 \%$ \\
\end{tabular}

$a_{\mathrm{ij}} \cdot \mathrm{X}_{\mathrm{i}} \cdot \mathrm{X}_{\mathrm{j}}$ correspond to the interactions.

$\mathrm{n}$ : the number of realized experiments

$\mathrm{p}$ : the number of estimated parameters from the model

After the point estimate of effects (Fig.1), the model is written as:

(2) $Y=1.894+0.260 X_{1}+0.127 X_{2}+0.047 X_{3}+$ $0.025 X_{4}-0.107 X_{1} X_{2}-0.006 X_{1} X_{3}-0.063 X_{1} X_{4}$ $+0.140 X_{2} X_{3}+0.111 X_{2} X_{4}-0.007 X_{3} X_{4}$

\subsection{The significance of effects}

According to the test of significance of effects (test "t") of the study (Fig.1), we noticed that at $\mathrm{p}<0.0001$, brine, lactic acid and citric acid have a significant effect on the decrease in $\mathrm{pH}$, on the contrary to the lactic ferment, which does not have any significant effect.

We also noted that the interactions between brine and lactic acid, between brine and ferment lactic, between lactic acid and citric acid and between lactic acid and lactic ferment have significant effects on the decrease in $\mathrm{pH}$, unlike the interactions between brine with citric acid and citric acid with lactic ferment which do not have a significant effect $(p<0.0001)$.

The mathematical model is written as

( 3 ) $Y=1.894+0.260 X_{1}+0.127 X_{2}+0.047 X_{3}$ $-0.107 X_{1} X_{2}-0.063 X_{1} X_{4}+0.140 X_{2} X_{3}+0.111$ $\mathrm{X}_{2} \mathrm{X}_{4}$
Since $\mathrm{Y}$ represents the decrease in $\mathrm{pH}$, and since the aim is to increase its value, it is the brine which has the most important effect, followed by lactic acid, while citric acid has relatively little effect.

As to the effect of the interactions, it is the interaction between lactic acid and citric acid that was the most important effect, followed by the effect of the interaction between lactic acid and lactic ferment, and then, the effect of the interaction between brine and lactic acid; the interaction between brine and lactic ferment has the least effect.

Interpretation of principal effects:

Total salt effect: when the content of salt in the juice varies from $10 \%$ to $20 \%$, the value of $Y$ increases by $2 \times 0.260=0.520$. To increase $Y$ (in other words, to improve the decrease in $\mathrm{pH}$ ), it is therefore necessary to take a brine of $20 \%$.

Lactic acid total effect: when the content of lactic acid passes from $0.1 \%$ to $1 \%$, the value of $Y$ increases by $2 \times 0.127=0.254$. So to increase $Y$, it is therefore necessary to use $1 \%$ of lactic acid.

Interpretation of the interaction:

Brine with lactic acid: when the content of the two factors varies respectively from $10 \%$ to $20 \%$ and from $0.1 \%$ to $1 \%$, the value of $Y$ decrease by 2 $x 0.047=0.094$. To increase $Y$, both factors in the interaction have to be at their lowest levels.

We indeed noticed that the interaction between lactic acid and citric acid, and between lactic acid lactic ferment do not result in a stronger decrease in $\mathrm{pH}$ unless the factors in the interaction are at their 
Table 3

Matrix of experiments

\begin{tabular}{|c|c|c|c|c|c|c|}
\hline No test & $\begin{array}{c}\text { Average } \\
\text { X0 }\end{array}$ & $\begin{array}{c}\text { Brine } \\
\text { X1 }\end{array}$ & $\begin{array}{l}\text { Lactic acid } \\
\qquad 2\end{array}$ & $\begin{array}{c}\text { Citric acid } \\
\quad \times 3\end{array}$ & $\begin{array}{l}\text { Lactic } \\
\text { ferment } \\
\text { X4 }\end{array}$ & $\begin{array}{c}\text { Response Y } \\
\text { decrease in } \\
\text { the pH }\end{array}$ \\
\hline 1 & +1 & -1 & -1 & -1 & -1 & 1.89 \\
\hline 2 & +1 & +1 & -1 & -1 & -1 & 2.25 \\
\hline 3 & +1 & -1 & +1 & -1 & -1 & 0.94 \\
\hline 4 & +1 & +1 & +1 & -1 & -1 & 2.17 \\
\hline 5 & +1 & -1 & -1 & +1 & -1 & 1.14 \\
\hline 6 & +1 & +1 & -1 & +1 & -1 & 2.13 \\
\hline 7 & +1 & -1 & +1 & +1 & -1 & 2.21 \\
\hline 8 & +1 & +1 & +1 & +1 & -1 & 2.22 \\
\hline 9 & +1 & -1 & -1 & -1 & +1 & 1.35 \\
\hline 10 & +1 & +1 & -1 & -1 & +1 & 1.95 \\
\hline 11 & +1 & -1 & +1 & -1 & +1 & 2.14 \\
\hline 12 & +1 & +1 & +1 & -1 & +1 & 2.08 \\
\hline 13 & +1 & -1 & -1 & +1 & +1 & 1.22 \\
\hline 14 & +1 & +1 & -1 & +1 & +1 & 2.21 \\
\hline 15 & +1 & -1 & +1 & +1 & +1 & 2.18 \\
\hline 16 & +1 & +1 & +1 & +1 & +1 & 2.23 \\
\hline Effect & $\mathrm{a} 0$ & $\mathrm{a} 1$ & a2 & a3 & a4 & \\
\hline Low level & & $10 \%$ & $0.1 \%$ & $0.1 \%$ & $0.5 \%$ & \\
\hline High level & & $20 \%$ & $1 \%$ & $1 \%$ & $2.5 \%$ & \\
\hline
\end{tabular}

\begin{tabular}{|c|c|c|c|c|}
\hline \multicolumn{5}{|c|}{ Analysis of Variance } \\
\hline Source & DF & Sum of Squares & Mean Square & F Ratio \\
\hline Model & 10 & 6,4471667 & 0,644717 & 6,9898 \\
\hline Error & 37 & 3,4127583 & 0,092237 & Prob $>\mathrm{F}$ \\
\hline C. Total & 47 & 9,8599250 & & $<.0001$ \\
\hline
\end{tabular}

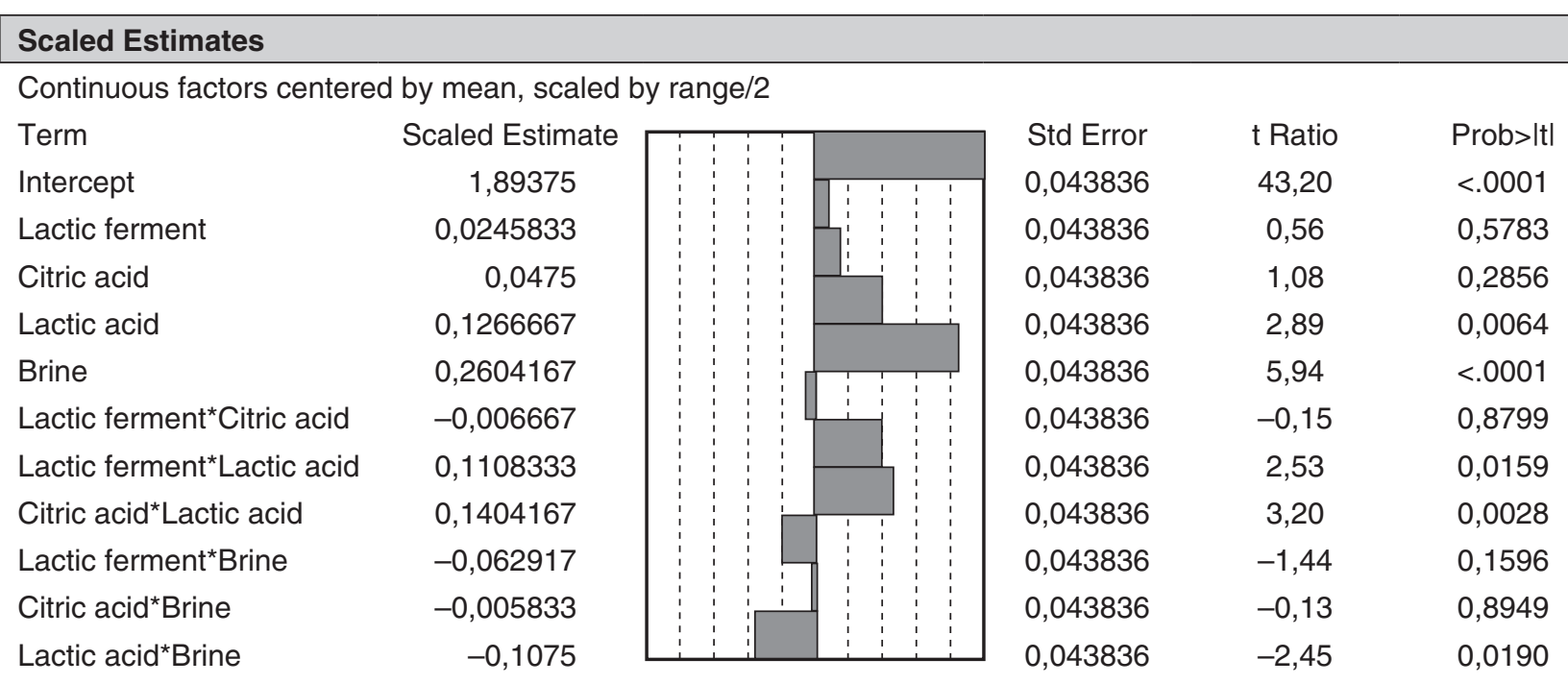

Figure 1.

Statistical calculations of the mathematical model of $\mathrm{pH}$ decrease for caper fermentation. 

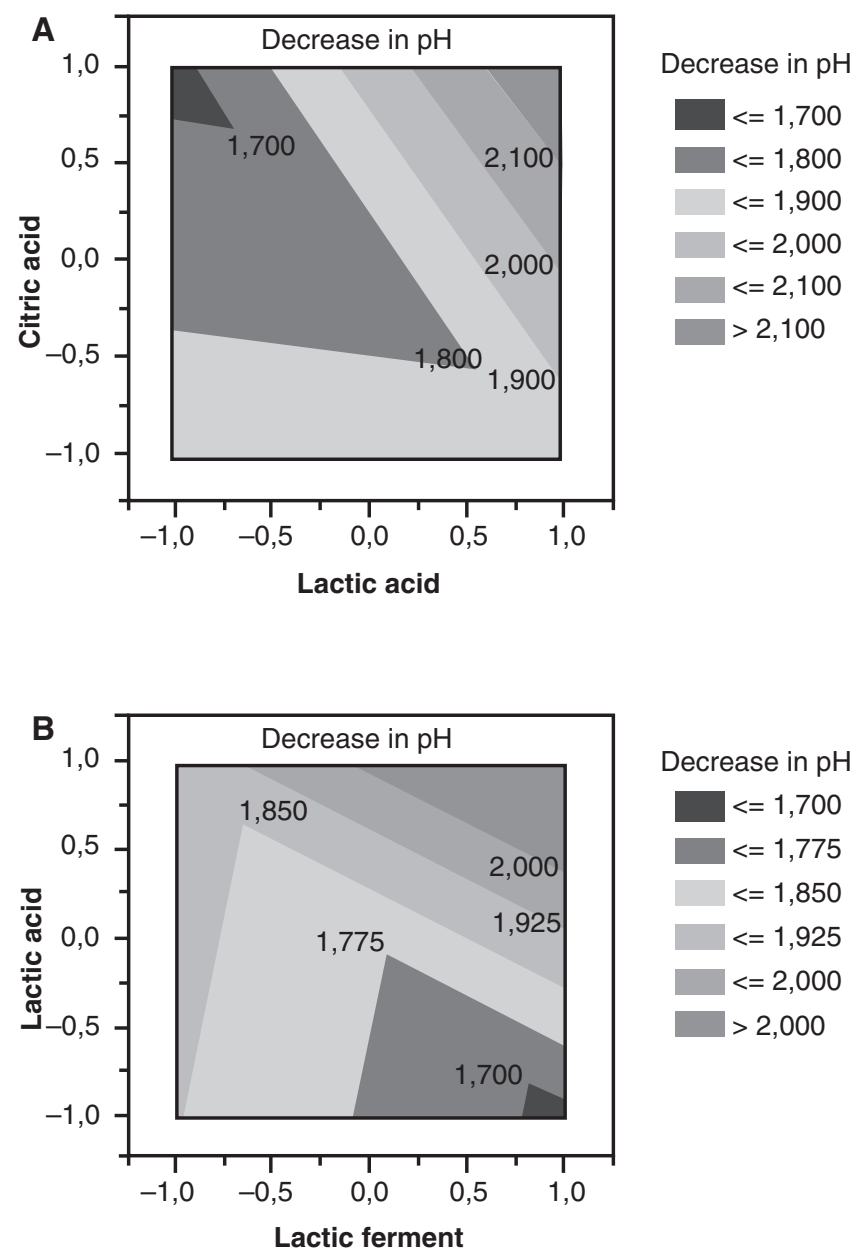

Figure 2.

Response surface. (A) Interaction of lactic acid with citric acid; (B) lactic acid with lactic ferment.

highest height levels $(+1)$, that is to say, lactic acid with the value of $1 \%$, citric at $1 \%$, as well, and lactic ferment with the value of $2.5 \%$.(Fig.2-A et Fig.2-B).

\subsection{Analysis of variance}

The aim is to compare the sum of differences squares due solely to regression (therefore to the model) with the sum of squares of the residues with the help of the $F$ test. We noticed that $F$ (observed) $>F(0.0001)$ (Fig.1) and therefore we accept the hypothesis of the validity of the model (equation 3 ).
( 3 ) $Y=1.894+0.260 X_{1}+0.127 X_{2}+0.047 X_{3}-$ $0.107 X_{1} X_{2}-0.063 X_{1} X_{4}+0.140 X_{2} X_{3}+0.111 X_{2} X_{4}$

\section{CONCLUSIONS}

By way of conclusion, we can say that the largest decrease in $\mathrm{pH}$ is produced when the factors are at their highest levels $(+1)$ of the domain of their variations.

\section{ACKNOWLEDGMENTS}

This study was supported by the group MAROCAPRES, The present worldwide leader in the field of the processing of capers.

\section{REFERENCES}

Akgül a. 1996. A rediscovered flavor: Capers (Capparis spp.). Gıda 21, 119-128 (in Turkish).

Akinrele IM. 1970. Fermentation studies on maize during the preparation of a traditional African starch-cake food. J. Sci. Food Agric. 21, 619-625.

Alvarruiza, Rodrigo M, Miquel J, Giner V, Feria A, Vila R. 1990. Influence of Brining and Packing Conditions on Product Quality of Capers. J. Food Science. 55, 196-198.

Arslan D, Unver A, Özcan M. 2007. Determination of optimum fermentation quality of capers (Capparis ovata desf. var. canescens) in different brine conditions. J. Food processing and preservation 32, 219-230. 
Aukrust TW, Blom A, Sandtory BF, Slinde E. 1994. Interactions between starter culture and raw material in lactic acid fermentation of sliced carrot. Lebensm.Wiss. Technol. 27, 337-341.

Fernández Gonzalez MJ, García García P, Garrido Fernández A, Durán Quintana MC. 1993. Microflora of the aerobic preservation of directly brined green olives from Hojiblanca cultivar. J. Applied Microbiology 75, 226-233.

Fleming HP, Feters RF. 1981. Use of microbial cultures: Vegetable products. Food Technol. 35, 84.

Fleming HP, Feeters RF, Etchells L, Bell TA. 1984. Pickled vegetables. In Compendium of Methods for the Microbiological Examination of Foods (M.L. Speck, ed.) American Public Health Association, Washington, DC, pp. 663-681.

Giuffrida D, Salvo F, Ziino F, Toscano G, Dugo G. 2002. Initial investigation on some chemical constituents of capers (Capparis spinosa L). J. Food Science. 14, 25-33.

Goupy J. 2005. Pratiquer les plans d'expériences. DUNOD/ L'usine nouvelle, French.

Goupy J, Creighton L. 2009. Introduction aux plans d'expériences. DUNOD/L'usine Nouvelle, French.

Joachim V. 2006. Utilization of renewables for lactic acid fermentation. J. Biotechnology 1, 1428-1432.

Leal-Sánchez MV, Ruiz-Barba JL, Sánchez AH, Rejano L, Jimenez- Diaz R, Garrido A. 2003. Fermentation profile and optimization of green olive fermentation using L. plantarum LPC010 as a starter culture. Food Microbiol. 20, 421-430.

Leroy F, Vuyst LD. 2004. Lactic acid bacteria as functional starter cultures for the food fermentation industry. Trends Food Sci. Technol. 15, 67-78.

McDonald LC, Shieh DH, Fleming HP, Feeters RF, Thompson RL. 1993. Evaluation of malolactic-deficient strains of Lactobacillus plantarum for use in cucumber fermentations. Food Microbiol. 10, 489-499.

Tolone M, Rajaniemi S, Pihlava JM, Johansson T, Saris PEJ, Ryhänen EL. 2004. Fermentation of nisin, plant derived biomolecules and antimicrobial activity in starter culture fermentations of sauerkraut. Food Microbiol. 21, 167-179.

Marsilio V, Seghetti L, lannucci E, Russi F, Lanza B, Felicioni M.2005._Use of a lactic acid bacteria starter culture during green olive (Olea europaea L cv Ascolana tenera) processing. J. Science of Food and Agriculture. 85, 1084-1090.

Montaño A, Sánchez AH, Castro A. 2000. Changes in the Amino Acid Composition of Green Olive Brine due to Fermentation by Pure Culture of Bacteria. J. Food Science 65, 1022-1027.

Mugula JK, Narvhus JA, Sorhaug T. 2003. Use of starter cultures of lactic acid bacteria and yeasts in the preparation of togwa, a Tanzanian fermented food. Int. J. Food Microbiol. 83, 307-318.

Oberman H, Libudzisz Z. 1998. Fermented milks. In Microbiology of Fermented Foods, Vol. 1 (B.J.B. Wood, ed.). Blackie Academic \& Professional, London, U.K,pp. 308-350

Oyewole OB, Odunfa SA. 1990. Characterization and distribution of lactic acid bacteria in cassava fermentation during fufu production. J. Appl. Bacteriol. 68, 145-152.

Özcan M. 1999. Use of yoghurt, lactic acide and starter in fermentation in capers (Capparis spp.) flower buds. Food Sci. Technol. 5-13.

Özcan M. 2001. Pickling caper flower buds. J. Food Quality 24, 261-269.

Özcan M, Akgul a. 1998. Influence of species, harvest date and size on composition of capers (Capparis spp) flower buds. Nahrung-Food 42,102-105.

Özcan M, Akgula. 1999. Some compositional characteristics of capers (Capparis spinosa) seed and oil. Grasas y Aceites 50, 49-52.

Pérez Pulido R, Ben Omar N, Abriouel H, Lucas López R, Martínez Cañamero M, Guyot JP, Gálvez A. 2007. Characterization of lactobacilli isolated from caper berry fermentations. J. Applied Microbiology 102 , 583-590.

Gardner NJ, Savard T, Obermeier P, Caldwell G, Champagne CP. 2001. Selection and characterization of mixed starter cultures for lactic acid fermentation of carrots, cabbage, beet and onion vegetable mixtures. Int. J. Food Microbiol. 64, 261-275.

Giraud E, Champailler A,Rimbault M. 1994. Degradation of raw starch by a wild amylolitic strain of $L$. plantarum. Appl. Environ. Microbiol. 60, 4319-4323.

Rodrigo M, Lazaro M, Alvarruiz A, Giner V. 1992. Composition of capers (Capparis spinosa): influence of cultivar, size, and harvest date. J. Food Sci. 57, 1152-1154.

Romeo V, Ziino M. 2007. Flavour profile of capers (Capparis spinosa L) from the Eolian Archipelago by HS-SPME/ GC-MS. Food Chemistry 101, 1272-1278.

Yoon KY,Woodams EE, Hang YD. 2005. Fermentation of beet juice by beneficial lactic acid bacteria. Lebensm.Wiss. Technol. 38, 73-75.

Recibido: $15 / 1 / 10$ Aceptado: 15/3/10 